\title{
Occupational Stress as correlates of Emotional Intelligence among Government School Lecturers (P.G.T)
}

\author{
Chanderkant Gorsy ${ }^{1} *$, Ritu Goyat ${ }^{1}$, Madhu Anand ${ }^{2}$
}

\section{ABSTRACT}

Emotions play an important role in the life of an individual and one requires a higher emotional intelligence to lead an effective life. We need to study the emotional aspects of school lecturer as they go on with their normal lives. The current study was planned to analyze the relationship between emotional intelligence and occupational stress. The sample consists of 102 school lecturer taken from government school. Further, the association of emotional intelligence with occupational stress of these school lecturers was analyzed. 'Emotional intelligence scale' was administered on the selected sample to assess emotional intelligence and occupational stress index', was used for measuring various components of occupational stress of these school lecturers. . The results showed that (i) occupational stress has a significant negative correlation with emotional intelligence (ii) Political pressure and Role overload have significant negative correlation with emotional intelligence, (iii) Role ambiguity, role conflict, responsibility for person and under- participation doesn't show any significant relation with emotional intelligence and (iv) Stepwise regression analysis revealed two predictors of emotional intelligence i.e. political pressure and role overload, jointly account for $.115 \%$ of variance in emotional intelligence.

Keywords: Emotional Intelligence, Occupational Stress, Role overload, School Lecturers

Cascio, (2001) noted at the beginning of 21st century that it is a time of globalization, information revolution, and pace in every sphere of life. The most important effects of these can be seen in the business world, and they can manifest themselves as changes that organizations make in their structures, strategies, activities, and technologies (Langley, 2000). Constantly changing organizations impose new roles and duties on their employees, and the employees who want to handle new roles and duties need to have a good intelligence quotient (IQ) and a good emotional quotient (EQ) in the processes of decision making and problem solving.

The 21st century has also been designated an era of stress where individuals face stress in their organizational as well as in their daily lives. Although society has a set of legal regulations to

\footnotetext{
${ }^{1}$ Ph.D. Scholar, Department of Psychology, Maharshi Dayanand University, Rohtak

${ }^{2}$ Professor, Department of Psychology, Maharshi Dayanand University, Rohtak *Corresponding Author (C) 2015 I C Gorsy, R Goyat, M Anand; licensee IJIP. This is an Open Access Research distributed under the terms of the Creative Commons Attribution License (http://creativecommons.org/licenses/by/2.0), which permits unrestricted use, distribution, and reproduction in any Medium, provided the original work is properly cited.
} 
help individuals live in a healthy manner, these regulations do not eliminate stress. Thus, a completely stress-free life is impossible, and stress becomes a characteristic of human existence.

Teaching profession has historically been viewed as the labor of love and kindness. It has many intrinsic and extrinsic rewards for people entering the pedagogical arena. However, teaching is not without its inherent problems. Problems associated with job related stress remain at the top of many teachers' list. A teacher has to face innumerable challenges and play different roles in his/her institution. He/she not only plan lessons but also organize activities, maintain necessary records, make purchases, administer time-table, oral and aural teaching aids, adopt new techniques of communication and motivate the students by words and deeds. Thus, teacher is expected to possess a multifaceted personality. Under these circumstances, it is but natural that teachers will remain under stress which is sure to affect their effectiveness while teaching.

In recent years, it has become a global concern, considering that about as many as a third of the teachers surveyed in various studies around the world reported that they regarded teaching as highly stressful (Borg, 1990). The level of stress experienced by P.G.T teachers has increased manifold than teachers at other levels at the school level. Excessive workload and teaching hours, role ambiguity, poor working conditions, overcrowded classes, uncongenial working environment, scarcity of resources, conflicting peer relations, frequently changing curriculum, assessment and evaluation strategies, accountability, lack of job security, lack of public esteem, meager salaries, indifferent students and parents behavior, professional development, fatigue, frustration, stagnation, boredom, and loss of motivation or enthusiasm and unsupportive parents, etc. contribute towards teacher stress (Blase, 1986; Manthei \& Solman, 1988; Whitehead \& Ryba, 1995; Travers \& Cooper, 1996; Pithers \& Sodon, 1998; Griffith et al., 1999; Kyriacou, 2001; Butt et al., 2005; Johnson et al., 2005; Meng \& Liu, 2008; Shernoff et al., 2011).

The amount and degree of stress a teacher experiences may be related to his negative selfperception, negative life experiences, low morale, and the struggle to maintain personal values and standards in the classroom (Worrall \& May, 1989). Kyriacou (2001) stated that "the stress experienced by a particular teacher will be unique to him or her, and will depend on the precise complex interaction between his or her personalities, values, skills, and circumstances”.

Moreover, according to Milstein and Farkas (1988), while the stressors (e.g. students' misbehaviors and discipline problems, students' poor motivation for work, heavy workload and time pressure, role conflict and role ambiguity, conflicting staff relationships in school management and administration, and pressure and criticisms from parents and the wider community) are found to be quite common across settings in the teaching profession, teachers do not react identically to these common stressors. Specifically, some teachers might develop psychological symptoms of varying severity, ranging from mild frustration, anxiety, and irritability to emotional exhaustion as well as psychosomatic and depressive symptoms (Kyriacou \& Pratt, 1985). 
Occupational stress has been increasing in the field of education as cited by researcher (Blix and Others, 1994; Sowa and Others, 1994; Chen and Miller, 1997; Chaplain, 2001; Gersch and Teuma, 2005 and Plash and Piotrowski, 2006) with reasons given from work load to demands of the administrator and parents. Occupational stress can make teachers ineffective and inefficient in their roles (Eskridge and Coker, 1985; Farber, 1984; Schamer and Jackson, 1996). It can have a negative influence on schools, overall teaching performances, the physical and emotional well being of teachers and students (Kyriacou, 1984; Philips, 1993).

Emotional intelligence is the ability of expressing feeling, expressing, understanding, and sentiment regulation. Emotional intelligence is a predictor of leadership ability through increasing focus on studying the ability to understand and manage men and women and to act wisely in human relations (Thorndike, 1920). High emotional intelligence individuals can better perceive emotions, use them in thought, understand their meanings, and manage emotions better than others. Solving emotional problems likely requires less cognitive effort for this individual. The person also tends to be higher on verbal, social and other intelligences (Mayer, Salovey and Caruso, 2004).

According to Salovey, Bedell, Detweiler, \& Mayer (2000), individuals differ as to their abilities to practice effective control over their emotional lives. Such individual differences are now thought of as differences in emotional intelligence (Salovey \& Mayer, 1990). Oginska-Bulik (2005) held that the ability to effectively deal with emotions and emotional information in the workplace assists employees in addressing occupational stress and retaining psychological health.

An employee with high emotional intelligence can deal with work environment stress. (Cooper et al., 2001). Recent studies have argued that such organizationally expected emotions are closely related to occupational stress (Grandey, 2002; Morris \& Feldman, 1996; Tolich, 1993; Wharton, 1993). Also a study conducted by Gohm, Corser, \& Dalsky (2005) revealed that emotional intelligence was associated with relatively lower reported stress levels. Slaski and Cartwright (2002) found that managers high in emotional intelligence revealed less subjective stress and had better physical and psychological well-being.

Similarly, Gardner and Stough (2003) revealed negative relationship between emotional intelligence and occupational stress. Saddam Hussain Rahim (2008) found that emotional intelligence competencies have the profound impact on stress, the psychological problems of employees and seeks to the solutions in the light of emotional intelligence competencies have a positive and strong impact on stress. The emotional intelligence is very important factor for prediction of teachers' health and also the correlation of emotional intelligence and occupational stress is significant (Mohammad Ali Mohammadyfar, et al., 2009). 
Further, Nina Ogniska (2005) confirmed an essential, but not very strong, the role of emotional intelligence in perceiving occupational stress and preventing employees of human services from negative health outcomes. The ability to effectively deal with emotions and emotional information in work place assists employees in coping with occupational stress.

In Indian studies, Sanjay Kumar Singh (2008) found no significant difference in the level of emotional intelligence and perceived role of stress between genders, but significantly negative relationships of emotional intelligence with organizational role of stress for both gender and medical professionals as a whole. Darolia and Darolia (2005) conducted a research on the role of emotional intelligence in coping with stress and emotional control behavior and found that emotionally intelligent people who are able to understand and recognize their emotions, manage themselves to keep under control in stressful situation. Sing and Sing (2008) conducted a study on the relationship between emotional intelligence and stress among medical professionals in their organizational lives. The study reveals significantly negative relationship of emotional intelligence with stress for both the genders of medical professionals.

P.G.T teachers are expected to fill many roles in their daily tasks. These roles may include assessor, planner, curriculum developer, information provider, role model, facilitator, and resource developer. As a result of balancing these many roles, stress will always be a part of the teaching profession. Research suggests that stress and emotion are related constructs that do not occur independently from one another. The experience of stress is the manifestation of negative emotions triggered by danger, threats or challenges (Slaski \& Cartwright, 2003). The important role that emotions play in the occupational stress process is only just being recognized. As emotions are difficult to measure in the workplace, they have generally been ignored in organizational research. However, the emergence of emotional intelligence has lead to a new focus on the role of emotions in the workplace. Despite the interest in workplace emotional intelligence, very little empirical research has examined the role emotional intelligence may play in occupational stress. This study systematically examines the role of emotional intelligence on occupational stress among Government School Lecturer (P.G.T)

\section{OBJECTIVES}

- To study the relationship of various components of occupational stress with emotional intelligence among government school lecturers (P.G.T.)

- To explore whether various components of occupational stress significantly predict emotional intelligence.

\section{Hypotheses}

In the present research the following hypotheses were proposed: 
- Emotional intelligence would be a significantly correlated with various components of occupational stress among government school teachers (PGT).

- Some of the occupational stress components would significantly predict emotional intelligence among government school teachers (PGT).

\section{METHODOLOGY}

\section{Sample}

To meet the objectives of the present study 102 individuals within the age range of 27 to 40 years. All the participants are working as P.G.T government teachers in Govt. co-educational senior secondary schools located at 5 districts of urban and rural areas of Haryana. All the P.G.T teachers holds at least three years of minimum teaching experience and living with family members.

\section{Tools}

- Occupational Stress Index [OSI; Srivastava \& Singh, (1984)]: To measure job stress this index may be conveniently administered to all categories of employees. The scale consisted of 46 items, each to be rated on five point scale, out of which 28 were true keyed and rests 18 were false keyed. The validity of Occupational stress index was determined by computing co-efficient of correlation between scales on the OSI and the various measures of job attitude and job behavior. Split half method was applied to establish the reliability of the scale which was found to be 0.935 by the authors.

- Emotional Intelligence Scale [EIS; Bhattacharya, Dutta \& Mandal, (2004)]: It was prepared by It consists of 40 items out of which 20 items are positive and other 20 items are negative. Items are to be answered on a five point scale ranging from never true to always true, with a possible range of scores from 40 to 200. A high score indicates high emotional intelligence. The test-retest reliability was 0.94 (alpha coefficient 0.87 ) and the correlation ( $\mathrm{r}=0.75)$, between Indian version of the scale and Schutte Emotional Intelligence Scale, indicates the validity of the present scale.

\section{Procedure}

After getting the formal permission from the Principals' of concerned institutes, data was collected during working hours. To initiate the study participants were briefed about the nature and the purpose of the research in order to receive the reliable data. They were informed that any provided information by them would be used only for research purpose and assured about the confidentiality of the data. Instructions were given regarding the questionnaires as per the respective manuals. The scales were filled in by the participants and collected immediately after completion. 


\section{Statistical Analyses}

To arrive at the final results and reveals the trends pertaining to the variables under the study descriptive statistics and Pearson correlation were computed. Additionally, stepwise regression analysis was applied. The obtained results are presented in the following section.

\section{RESULTS \& DISCUSSION}

The results of statistical analysis for the present investigation has been presented with the help of tabulation which shows the descriptive statistical values (Table - I) for the said variables. It is evident from the mean values that for occupational stress components obtained scores are falling on the lower side ranging from 8.73 to 14.68 . Which means that majority of government teachers comprises the present sample experience less stress associated with their occupational demands.

Table I: Summary Table Showing Mean and S.D.'S For Total Sample $(N=102)$

\begin{tabular}{|l|l|l|}
\hline Variables & Mean & S. D. \\
\hline Emotional Intelligence (EI) & 167.50 & 8.17 \\
\hline Role Overload (RO) & 14.68 & 2.54 \\
\hline Role Ambiguity (RA) & 8.82 & 1.73 \\
\hline Role Conflict (RC) & 12.20 & 2.22 \\
\hline Political Pressure (PP) & 10.18 & 1.66 \\
\hline Responsibility for Person (RP) & 8.73 & 1.86 \\
\hline Under-Participation (UP) & 8.73 & 1.75 \\
\hline
\end{tabular}

Whereas mean scores $(\mathrm{M}=167.50 ; \mathrm{SD}=8.17)$ on the emotional intelligence are falling on higher side. Such trends reflect their tendency to make effective use of emotional abilities and maturity to deal with the stress full demands.

Table 2 reveals the inter-correlation outcomes for the present sample and shows the trend that emotional intelligence is strong correlated of political pressures $(r=-0.282 ; p \leq .01)$ and role overloading $(\mathrm{r}=-0.200 ; \mathrm{p} \leq .05)$ in negative direction. Additionally, no associations were observed among emotional intelligence, role ambiguity, role conflict, responsibility for person and under participation.

Table 2: Inter-Correlation between Six Components of Occupational Stress and Emotional Intelligence

\begin{tabular}{|l|l|l|l|l|l|l|}
\hline $\begin{array}{l}\text { Occupational } \\
\text { stress }\end{array}$ & $\begin{array}{l}\text { Role } \\
\text { overload }\end{array}$ & $\begin{array}{l}\text { Role } \\
\text { ambiguity }\end{array}$ & $\begin{array}{l}\text { Role } \\
\text { conflict }\end{array}$ & $\begin{array}{l}\text { Political } \\
\text { pressures }\end{array}$ & $\begin{array}{l}\text { Responsibility } \\
\text { for person }\end{array}$ & $\begin{array}{l}\text { Under } \\
\text { participation }\end{array}$ \\
\hline $\begin{array}{l}\text { Emotional } \\
\text { intelligence }\end{array}$ & $-.200^{*}$ & -.095 & -.050 & $-.282^{* *}$ & -.110 & .104 \\
\hline
\end{tabular}

${ }^{* *} \mathrm{p}<.01 ;{ }^{*} \mathrm{p}<.05$ 
Further, there is positive relationship between under-participation and emotional intelligence among school lecturers (Table 2). Although under-participation has a positive relationship with emotional intelligence (Table 2) yet it does not comes out as a predictor of emotional intelligence. It has been find out that the correlation between role ambiguity, role conflict, responsibility for person and under-participation with emotional intelligence is not significant (Table 2).

Table 3 represents the results for Stepwise multiple regression analysis and revealed that two significant predictors of emotional intelligence are political pressure and role overload. It could be interpreted from the regression analysis that political pressure comes out to be the most pertinent predictor of Emotional intelligence, as it entered the equations at step one with the $\mathrm{R}$ value of 0.282 which indicates that "political pressure" accounts for $7.9 \%$ of variance in criterion variable (i.e. emotional intelligence) among school lecturers. The beta value showed that political pressure has a negative significant relationship with emotional intelligence.

Followed by political pressure, role overload contributed an additional 3.6\% of the variance over and above towards the emotional intelligence among the present sample.

Table 3 Summary of Stepwise Regressive Analysis Dependent Variable: Emotional Intelligence

\begin{tabular}{|l|l|l|l|l|l|l|l|}
\hline Steps & Predictors & Multiple R & $\mathbf{R}^{2}$ & $\mathbf{R}^{2} \Delta$ & $\mathbf{B}$ & $\mathbf{F}$ & $\mathbf{P}<$ \\
\hline 1 & $\begin{array}{l}\text { Political } \\
\text { pressure }\end{array}$ & .282 & .079 & .079 & -.282 & 8.622 & .001 \\
\hline 2 & $\begin{array}{l}\text { Role } \\
\text { overload }\end{array}$ & .339 & .115 & .036 & -.188 & 6.415 & .001 \\
\hline
\end{tabular}

From the results it seems clear that political pressure and role overload have a significant relationship with emotional intelligence and these two variables significantly predict school lecturer's emotional intelligence. Both occupational stress components (political pressure and role overload) jointly account for near about $11.5 \%$ ( $7.9 \%+3.6 \%$ respectively) of variance in the criterion variable (i.e. emotional intelligence).

Individuals have used various methods to handle stress, including using their intelligence, especially their emotional intelligence (Sirin, 2007). Several studies have suggested that individuals with high emotional intelligence are more capable of understanding and managing their emotions, which allows them to adjust to their surroundings and become more tolerant to challenging conditions, including stress (Bar-On, 1997; Goleman, 2005; Matthews et al., 2006). Emotional intelligence significantly contributes to reducing occupational stress by better 
identifying feelings of frustration and stress and, consequently, regulating those emotions (Cooper \& Sawaf, 1997).

\section{CONCLUSION}

The yielded results of the current study lead to the conclusion that enhancing teachers' emotional intelligence might have an effect on their occupational stress. Despite some limitations, this study extends past findings on teacher occupational stress and emotional intelligence and contributes to better understanding of these phenomena and how they are related. Based on the results of this study, school-based social and emotional learning programs should be developed for P.G.T teachers. Kremenitzer (2005) stated: “an increase in a teacher's emotional intelligence significantly impacts on student learning in a powerful way both in academic and interpersonal domains".

Greenberg (2002) also argued that emotionally intelligent teachers are less vulnerable to stress and might easily retrieve healthy information and action tendency within emotions, and avail themselves of this information to better react to stressors as well as to inspire adaptive action. The findings also underlie the importance of establishing some courses for P.G.T teachers especially young and less experienced ones to focus particularly on raising teachers' awareness of stress levels and learning judicious strategies for surmounting chronic stress.

The lack of diversity among the participants in the present study creates difficulty in generalizing to other settings. Therefore, it is recommended that the present study be replicated with a larger and more representative and diverse sample of the P.G.T teacher population, among middle, and high school level teachers. This may identify differences in emotional intelligence and occupational stress among different teaching levels. Also for obtaining a more precise estimate of teacher emotional intelligence and occupational stress, future research should combine selfreporting measures with other measures based on objective performance.

\section{REFERENCES}

Bar-On, R. (1997). The Emotional Quotient Inventory (EQ-I): Technical Manual. Toronto: Multi-Health Systems.

Bhattacharya,M., Dutta, A. K, \& Mandal, M. K. (2004). Factor structure of emotional intelligence in India. Psychological Studies, 49, 142-146.

Blase, J. (1986). A qualitative analysis of sources of teacher stress: consequences for performance. American Educational Research Journal, 23(1), 13-40.

Blix, A. G. \& Others (1994). Occupational Stress among University Teachers. (EJ487448), Educational Research, Vol. 36. No.2,pp. 157-69.

Borg, M. (1990). Occupational stress in British educational settings: A review. Educational Psychology, 10, 103-126. 


\section{Occupational Stress as correlates of Emotional Intelligence among Government School Lecturers}

(P.G.T)

Butt, G., Lance, A., Fielding, A., Gunter, H., Rayner, S., \& Thomas, H. (2005). Teacher job satisfaction: lessons from the TSW pathfinder project. School Leadership and Management, 25(5): 455-471.

Cascio, W.F. (2001). Knowledge creation for practical solutions appropriate to a changing world of work. South African Journal of Industrial Psychology. 27(4): 14-16.

Chaplain, R. P. (2001). Stress and Job Satisfaction among Primary Head teachers: A Question of Balance? (EJ629337), Educational Management \& Administration, Vol. 29, No. 2, pp. 197-215.

Chen, M. \& Miller, G. (1997). Teacher Stress: A review of the International Literature. ERIC Document ED410187.

Cooper, C. L., Dew, P. J., O’ Driscoll, M. P. (2001). Organizational stress: A review and Critique of Theory, Research, and Applications. (Ed.), Thousand Oaks: Sage Publications.

Cooper, R., \& Sawaf, A. (1997). Executive EQ: Emotional intelligence in leadership and organizations. Grosset/Putnam, New York.

Darvish, H, Nasrollahi, A. (2011). Studying the Relations between Emotional Intelligence and Occupational Stress: A Case Study at Payame Noor University. Journal of Economic Sciences Series.; LXIII (2): 38-49.

Eskridge, D. H. \& Coker, D. R. (1985). Teacher Stress: Symptoms, Causes, and Management techniques. The Clearing House, Vol. 58, pp. 387-390.

Farber, B. A. (1984). Stress and burnout in suburban teachers. The Journal of Educational Research, 77 (6), 325-331.

Gardner, L. J. \& Stough, C. (2003). Exploration of the relationship between workplace, emotional intelligence, occupational stress and employee health. Australian Journal of Psychology, Vol.55, pp. 181-95.

Gersch, I. \& Teuma, A. (2005). Are Educational Psychologists Stressed? A Pilot Study of Educational Psychologists' Perceptions (EJ694763). Educational Psychology in Practice, Vol. 21, No. 3, pp. 219-233.

Gohm, L. C, Corser, C. G., \& Dalsky, J. D. (2005). Emotional intelligence under stress: Useful, unnecessary, or irrelevant? Personality and Individual Differences, 39, 1017-1028.

Goleman, D. (2005). Why is emotional intelligence more important than IQ? (In Turkish). (Trans. By Banu S. Yüksel). Varlık Publications, İstanbul, Turkey.

Greenberg, L. S. (2002). Emotion-focused therapy. Washington, DC: American Psychological Association.

Griffith, J., Steptoe, A., \& Cropley, M. (1999). An investigation of coping strategies associated with job stress in teachers. British Journal of Educational Psychology, 69(4), 517-531.

Harrod, R. N., \& Sheer, D. S. (2005). An exploration of adolescence emotional intelligence in relation to demographic characteristics. Adolescence, 40 (159).

Johnson, S., Cooper, C., Cartwright, S., Donald, I., Taylor, P. \& Millet, C. (2005). The experience of work-related stress across occupations. Journal of Managerial Psychology, $20(1 / 2), 178-187$.

Kremenitzer, J. P. (2005). The emotionally intelligent early childhood educator: self-reflective journaling. Early Childhood Education Journal, 33 (1), 3-9. 


\section{Occupational Stress as correlates of Emotional Intelligence among Government School Lecturers}

(P.G.T)

Kyriacou, C. (1984). Teacher stress and Burnout: An International review. Educational Research, Vol. 29, pp. 146-152.

Kyriacou, C. (2001). Teacher stress: Directions for future research. Educational Review,53 (1), 27-35.

Kyriacou, C. \& Pratt, J. (1985). Teacher stress and psychoneurotic symptoms. British Journal of Educational Psychology, 55, 61-64.

Langley A (2000). Emotional intelligence - a new evaluation for management development? Career Dev Int. 5(3): 177-183.

Manthei, R. J. \& Solman, R. (1988). Teacher stress and negative outcomes in Canterbury state schools. New Zealand Journal of Educational Studies, 23, 145-163.

Matthews, G., Emo., A. K., Funke, G., Zeidner, M., Roberts, R. D., Costa, P. T., \& Schulze, R. (2006). Emotional intelligence, personality, and task-induced stress. Journal of Experimental Psychology: Applied, 12 (2), 96-107.

Mayer, J. D., Salovey, P. \& Caruso, D. R. (2004). A further consideration of the issues of emotional intelligence. Psychological Inquiry, Vol. 15, pp. 249-255.

Mendes, J. (2002). The Relationship between emotional intelligence and occupational burnout in secondary school teachers. Dissertation Abstracts International, 63, (10), 4951A.

Meng, L. \& Liu, S. (2008). Mathematics teacher stress in Chinese secondary schools. Journal of Educational Enquiry, 8(1), 73-96.

Milstein, M. M., \& Farkas, J. (1988). The overstated case of educator stress. Journal of Educational Administration, 26, 232-249.

Mohammad Ali Mohammadyfar, Mohammad S.Khan, \& Bahman Kord Tamini. (2009). The effect of emotional intelligence and job burnout on mental and physical health. Journal of Indian Academy of Applied Psychology, Vol.35, No.2.

Nina Ogniska (2005). Emotional intelligence in the work place; Exploring its effects on occupational stress and health outcomes in human service workers. International journal of Occupational medicine and environmental health, vol.18. No.2

Oginska-Bulik, N. (2005). Emotional intelligence in the workplace: Exploring its effects on occupational stress and health outcomes in human service workers. International Journal of Occupational Medicine and Environmental Health, 18 (2), 167-175.

Phillips, B. M. (1993). Stresses of teachers in public schools. In: Educational and psychological perspectives on Stress in students, teachers, and parents (pp.185-200). Clinical Psychology Publishing Co., Brandon, V. T.

Pithers, R. T. \& Soden, R. (1998). Scottish and Australian teacher stress and strain A comparative study. British Journal of Educational Psychology, 68(2), 269-279.

Plash, S. \& Piotrowski, C. (2006). Retention Issues: A Study of Alabama Special Education Teachers (EJ765810). Education, Vol. 127, No. 1, pp.125-128.

Saddam Hussain Rahim (2010). Emotional intelligence and stress: An Analytical study of Pakistan Banks. Economic survey of Pakistan 2008-09, ministry of Finance.

Salovey, P., \& Mayer, J. D. (1990). Emotional intelligence. Imagination, Cognition, and Personality, 9, 185-211. 
Salovey, P., Bedell, B. T., Detweiler, J. B., \& Mayer, J. D. (1999). Coping intelligently: Emotional intelligence and the coping process. In C.R. Snyder (Ed.), Coping: The psychology of what works (pp. 141-164). New York: Oxford Psychology Press.

Salovey, P., Bedell, B. T., Detweiler, J. B., \& Mayer, J. D. (2000). Current directions in emotional intelligence research. In M. Lewis, \& J. M. Haviland-Jones (Eds.), Handbook of emotions (2nd ed., pp. 504-520). New York: Guilford.

Sanjay Kumar Singh (2008). Managing role of stress through Emotional Intelligence; a study of Indian medico professionals. International journal of Indian Culture and Business Management,Vol.1,No.4.

Schamer, L. A. \& Jackson, M. J. (1996). Coping with stress: Commonsense about teacher burnout. Education Canada, Vol. 36, No. 2, pp. 28-31.

Shernoff, E.S., Mehta, T.G., Atkins, M.S., Torf, R. \& Spencer, J. (2011). A qualitative study of the sources and impact of stress among urban teachers. School Mental Health 3, 59-69.

Sirin, G. (2007). The relationship between teachers' emotional intelligence levels and their ways of coping up with stress (In Turkish). Master's thesis, Gazi University, Ankara, Turkey.

Slaski, M. \& Cartwright, S. (2002). Health, performance and emotional intelligence: An exploratory study of retail managers. Stress Health, Vol. 18, pp. 63-68.

Sowa, C. J. \& Others (1994). Occupational Stress within the Counseling Profession: Implications for Counselor Training. (EJ494322), Counselor Education and Supervision, Vol. 34, No. 1, pp. 19-29.

Srivastava, A.K. \& Singh, A.P. (1981). Occupation Stress Index. Manovaigyanik Parikshan Santhan, Varanasi.

Taylor, G. J. (2001). Low emotional intelligence and mental illness. In J. Ciarrochi, \& J. P. Forgas (Eds), Emotional intelligence in everyday life: A scientific inquiry (pp. 67-81). Philadelphia, PA: Taylor \& Francis.

Thorndike, E.L. (1920). Intelligence and its uses. Harper's Magazine, Vol. 140, pp. 227-235.

Travers, C. \& Cooper, C. (1993). Mental health, job satisfaction and occupational stress among UK teachers. Work \& Stress: An International Journal of Work, Health \& Organisations, 7(3), 203-219.

Tsaousis, I., \& Nikolaou, I. (2005) Exploring the relationship of emotional intelligence with physical and psychological functioning. Stress and Health 21, 77-86.

Ucar, F. (2004). The role of mind in stress, and cognitive and psychological disorders related to stress (In Turkish). Turkish Psychology Bulletin. 10(34-35): 85-102.

Whitehead, A.J. \& Ryba, K. (1995). New Zealand teachers' perceptions of occupational stress and coping strategies. New Zealand Journal of Educational Studies, 30, 177-188.

Worrall, N., \& May, D. S. (1989). Towards a person-in-situation model of teacher stress. British Journal of Educational Psychology, 59, 174-86. 